\title{
National Parks
}

\begin{abstract}
T a meeting of the Linnean Society held on December 8, the objects of national parks were discussed. The immediate cause of the discussion was a letter from Prof. J. B. Cleland, chairman of the Commissioners of the National Park at Belair, South Australia, who asked for "an authoritative definition of a National Park" and an expression of opinion as to how far facilities for sport and recreation should be allowed to replace the original flora and fauna, especially when the Park is near a large city.

Prof. T. G. B. Osborn, a former commissioner, gave an account, illustrated by lantern slides, of the Park at Belair. It is an area of 2,000 acres in the hills to the south-west of Adelaide, about eight miles by road from the city. Its history as a park dates from 1891, but the area has been preserved in a semi-wild state since shortly after the foundation of the Colony in 1837. Formerly known as the 'Government Farm', it served as a depot for horses of the Police and Survey Departments. The western end is relatively level, with open eucalypt forest (red gums, manna gums and peppermint) and grassy undergrowth. This is the part which has been most influenced by grazing of horses and clearings for sports grounds. From this area, which lies at about $850 \mathrm{ft}$. altitude, two narrow, steep-sided valleys run into the eastern part, which in one corner reaches $16,000 \mathrm{ft}$. The valley bottoms have been largely cleared of timber, though magnificent specimens of the original gums are left. Exotic trees have been planted among them, and the growth of grass encouraged. Here again, sport facilities and picnic facilities have been provided. Most of the steep valley sides and surrounding hills are relatively unaltered and have a covering of stringy-bark or pink gum trees with shrubby undergrowth. Some 350 species of indigenous flowering plants and ferns, including about 50 species of terrestrial orchids, have been recorded.
\end{abstract}

An area of seasonal swamp is of special interest as a habitat of the rare lycopod, Phylloglossum, and a terrestrial Isoetes. A measure of the interference with the flora is seen in the 150 species of alien plants naturalized in the Park. The indigenous mammalian fauna is probably extinct, but many interesting reptilian species remain. Eighty-one species of birds have been recorded. Like other parts of the Mount Lofty Ranges, the Park is liable to damage from fires during the dry season. The indigenous vegetation recovers rapidly after burning, but frequent forest fires open the way to invasion by alien species. Grazing by horses helps to keep the grass short, and so reduces the danger of fires during the dry season. The Commissioners have not a large grant for maintenance, so they welcomee the fees from depasturing horses. A considerable addition to revenue is obtained from the hire of sports grounds, tennis courts, and pavilions for picnics.

Sir Peter Chalmers Mitchell, speaking on behalf of the Society for the Preservation of the Fauna of the Empire, defined a national park as an area under public control, with unalterable boundaries, in which wild animal and plant life is preserved, and hunting or collecting only allowed under licence. He agreed that there is need to modify the definition to meet the case of smaller areas near towns, for it is unreasonable to expect that an area so situated should be left exclusively for naturalists.

Dr. Julian Huxley pointed out that this definition was meant primarily for Africa. As a member of the Standing Committee for National Parks of the Council for the Preservation of Rural England, he emphasized that a national park in Great Britain should be an extensive district of beautiful landscape left in traditional usage. Whilst in Africa the preservation of flora and fauna might be the chief object, in England possibilities for recreation, walking and camping in unspoilt countryside must take precedence. In his opinion, the Park at Belair in South Australia is too small to fulfil the functions of a national park, but it should be possible to restrict games to certain areas, and to establish sanctuaries in the wilder parts. The ideal of a national park for England embracing an extensive district (50-200 square miles) of wilder countryside, was developed by Mr. John Dower of the Committee for National Parks. The aim would be to preserve the beauty of landscape, allow access to the people and afford general protection of wild life.

Dr. G. Herbert Smith, speaking for the Society for the Promotion of Nature Reserves, said that, small though the Park at Belair is, its use for recreation and æsthetic enjoyment is not necessarily incompatible with protection of flora and fauna.

Prof. F. E. Weiss urged the importance of localizing sporting facilities and motor traffic and of maintaining strict reserves within the park for plants of special scientific interest. Mr. C. A. Gardner pointed out that one such reserve exists near W. Albany, Western Australia, for the preservation of Cephalotus, the endemic pitcher-plant. He emphasized the difficulty of conserving the Australian flora, owing to the fact that it is readily modified by recurrent fires and human access. Mr. H. I. Burkill reported an un. successful attempt to conserve an area of natural jungle in the Botanic Gardens, Singapore.

The inevitability of change was stressed by Dr. W. T. Calman, who pointed out that Nature is dynamic, not static, and that, unless the traditional occupations of the countryside are maintained, the flora and fauna of any reserve in Britain will alter in a few years.

Summing up, Dr. J. Ramsbottom said that the term 'Nation's Park', first used in America in 1842, was intended to mean an area of country left in its 'pristine state'.

Replying to the criticism of the inadequate area of the National Park, Belair, Prof. Osborn said that South Australia has also a flora and fauna reserve of about 200 square miles at the western end of Kangaroo Island. The vegetation and animals of this differ from those of the Mount Lofty Ranges; hence the importance of the small reserve at Belair. 